\title{
Colorectal cancer surgery in octogenarians
}

\begin{tabular}{|c|c|}
\hline \multirow[t]{5}{*}{ ABSTRACT } & $\begin{array}{l}\text { Objective: The incidence of colorectal cancer becomes higher among octogenarians as the life expectancy increases. } \\
\text { Whether advanced age is a risk factor for colorectal surgery is a matter of debate. In the present study, the clinical } \\
\text { results of octogenarians who underwent colorectal cancer surgery are discussed to find an answer to this question. }\end{array}$ \\
\hline & $\begin{array}{l}\text { Material and Methods: Data of } 63 \text { octogenarians who were operated in a tertiary colorectal surgery department bet- } \\
\text { ween January 1, } 2010 \text { and December 31, } 2013 \text { were reviewed retrospectively. Demographic data and preoperative, } \\
\text { peroperative, and postoperative parameters were evaluated. }\end{array}$ \\
\hline & $\begin{array}{l}\text { Results: Overall, } 57.2 \% \text { of the patients were men. The median age was } 81(80-89) \text { years. Cancer was located at } \\
\text { the right colon in } 17.5 \% \text {, left colon in } 50.8 \% \text {, and rectum in } 31.7 \% \text {. Eleven patients underwent emergency surgery } \\
(17.5 \%) \text {. The most common surgical procedure was low anterior resection in elective }(22.2 \%) \text { and Hartmann's pro- } \\
\text { cedure in the emergency setting }(9.5 \%) \text {. Stoma creation was more frequent among patients undergoing emergency } \\
\text { procedures ( } 42 \% \text { vs. } 6.8 \% ; p=0.0018) \text {. Histopathological diagnosis was adenocarcinoma in } 90.5 \% \text { of the patients, and } \\
34.9 \% \text { of the patients had stage IIIB disease. Surgical morbidity was significantly higher among patients who under- } \\
\text { went rectal resection ( } 66 \% \text { vs. } 10.2 \% ; p=0.0124) \text {. Medical morbidity was observed in } 10(15.9 \%) \text { patients. Preoperative } \\
\text { blood transfusion was a risk factor for morbidity }(83.4 \% \text { vs. } 29.8 \% ; p=0.0170) \text {. Length of total hospital stay was } 14 \\
\text { (3-39) days. Surgical ( } p=0.0004) \text { and medical ( } p=0.0288) \text { morbidity prolonged the length of total hospital stay. The } \\
\text { overall mortality rate was } 1.6 \% \text {. }\end{array}$ \\
\hline & $\begin{array}{l}\text { Conclusion: Colorectal surgery may be safely performed in octogenarians with acceptable morbidity and mortality } \\
\text { in specialized centers. }\end{array}$ \\
\hline & Keywords: Colorectal, morbidity, mortality, octogenarian, surgery \\
\hline
\end{tabular}

ORCID IDs of the authors: B.G. 0000-0002-9754-8755, T.Y. 0000-0003-1924-0795, 0̈.l. 0000-0002-9541-5035, E.0. 0000-0001-8593-5101.

\section{Cite this paper as: Gülcü B, Yılmazlar T, Işık 0 , Öztürk E. Colorectal cancer surgery in octogenarians. Turk J Surg 2018; 34(4): 271-275}

Department of General Surgery, Uludag University School of Medicine, Bursa, Turkey

This study was presented at the $15^{\text {th }}$ National Colon and Rectal Surgery Congress, May 19-23, 2015, Antalya, Turkey.

\section{Corresponding Author} Barış Gülcü

e-mail:drbarisgulcu@hotmail.com

Received:10.11.2017

Accepted: 26.01 .2018

Available Online Date: 18.09.2018

CC Copyright 2018

by Turkish Surgical Association

Available online at

turkjsurg.com

\section{INTRODUCTION}

The average life span was 50 years in the 1900s; it has increased to 75 years in 2000 . Currently, compared with the previous century, there are three times more people who are aged over 70 years and ten times more people aged over 80 years. The increasing life expectancy and increased number of elderly people are accompanied by an increasing number of elderly patients with cancer who require surgery owing to the increasing cancer incidence with advanced age (1). The majority of this group comprises patients with colorectal cancer, as half of all cases with colorectal cancer are present in patients over 70 years (2).

Octogenarians, whose population has been increasing the most in society, are also the patient group with the most increased colorectal cancer rates. Limited functional reserves, comorbid diseases, and frequent acute surgical problems of these patients make surgeons avoid performing an operation on them (3). However, several studies report promising outcomes for octogenarians $(4,5)$.

Since it is the only fully equipped and experienced tertiary center in our region, our clinic performs a remarkable number of surgeries on elderly patients. The outcomes of octogenarians were similar to those of younger patients after all general surgical procedures. The aim of the present report was to study the clinical outcomes of octogenarians who had operations in our clinic with a diagnosis of colorectal cancer.

\section{MATERIAL AND METHODS}

Octogenarian patients who underwent surgery for colorectal cancer in the Uludag University Department of General Surgery between January 1, 2010 and December 31, 2013 were retrospectively evaluated. Approval for the study was obtained from the local ethics committee. Informed consent was obtained from all patients to participate in the study. All of the procedures were performed by highvolume colorectal surgeons. Inclusion criteria comprised patient age $\geq 80$ years, diagnosis of colorectal cancer, and complete postoperative follow-up. 
Data on demographics, comorbid diseases, American Society of Anesthesiologists (ASA) score, tumor localization, admission type (emergency/elective), symptom duration time, need for preoperative blood transfusion, intent of the surgical procedure (palliative/curative), resection type, surgical procedure, stoma creation, histopathological diagnosis, disease stage, morbidity (surgical/medical), length of total hospital stay (LOS), and mortality development of the patients were documented. The ASA score was identified by an anesthesiologist preoperatively.

Surgical procedures were classified into three groups: right colon, left colon, and rectum. Colon from the ileocecal valve to the mid-transverse colon within the insertion of the middle colic artery was defined as the right colon. Colon from the mid-transverse colon to the rectosigmoid junction but not involving the rectum was defined as the left colon. Disease staging was performed based on the tumor node metastasis stage, which was most recently updated in 2009 and originally reported by both the American Joint Committee on Cancer and the Union for International Cancer Control in 1954.

We classified perioperative complications as surgical (surgical site infection, anastomotic leak, eventration, intra-abdominal abscess, and peroperative injury) or medical (atrial fibrillation, pneumonia, and urinary tract infection). All mortalities within 30 days after surgery, even if it was not associated with the performed surgical procedure, and all mortalities related to the surgery or any surgical complications were documented as mortality.

Statistical analyses were performed using the Statistical Package for Social Sciences (SPSS) for windows version 10.0 (SPSS Inc.; Chicago, IL, USA). Data were presented as mean \pm standard deviation or median (min-max) values. Ratios between the groups that were created according to various variables were compared using the Pearson's chi-square test and the Kolmogorov-Smirnov test. The magnitudes of the values between the groups were compared using the Mann-Whitney $U$ test. A p value $<0.05$ was considered as statistically significant in all analyses.

\section{RESULTS}

In total, 63 (8.2\%) of the 768 patients who underwent surgery for colorectal cancer in our clinic between January 1, 2010 and December 31, 2013 were octogenarians. There were 36 (57.2\%) men and 27 (42.8\%) women. The median age was 81 (80-89) years. There were 14 (22.2\%) patients who did not have any comorbid diseases. Fifteen patients had only cardiac comorbid diseases. However, the overall rate of cardiac comorbid diseases was $57.1 \%$ (alone in 15 patients and with other comorbid diseases in 21 patients). Only one patient was classified as ASA I, $71.5 \%$ were ASA II, and $26.9 \%$ were ASA III.

The primary tumor was located at the right colon in 11 (17.5\%), left colon in 32 (50.8\%), and rectum in 20 (31.7\%) patients. Rectal cancer was the most frequent type of cancer, followed by sigmoid (22.2\%) and rectosigmoid colon cancer (17.5\%). The median duration of symptoms was 40 days for patients with colon cancer throughout the colon, 90 days for right colon cancer,
Palliative procedures were performed in only 2 (3.2\%) patients, whereas curative surgery was performed in 61 (96.8\%) of them. The performed palliative procedures were bypass and transanal local excision. R0 resection was performed in 61 (96.8\%) patients, whereas R1 resection was performed in 1 (1.6\%) patient. There was only one patient with an unresectable mass. Eleven (17.5\%) patients underwent emergency procedures. Table 1 presents the performed surgical procedures. Hartmann's procedure and low anterior resection (LAR) were most frequently performed in emergency and elective operations, respectively.

A stoma was created in 19 (30.1\%) patients. End stoma was created in $14(73.7 \%)$ of them, whereas a diverting stoma with an anastomosis was created in 5 (26.3\%) patients. The rate of stoma creation was significantly higher in emergency operations $(p=0.0018)$. Adenocarcinoma with a rate of $90.5 \%$ was the most predominant pathological diagnosis. Table 2 shows the distribution of the disease stages. Stage IIIB was the most predominant stage with a rate of $34.9 \%$.

Six patients received blood transfusion in the preoperative period, and 5 (83.4\%) of them experienced postoperative morbidity. Receiving blood transfusion in the preoperative period was a risk factor for morbidity $(p=0.0170)$. Twelve $(19 \%)$ patients had surgical morbidity. Surgical site infection was the most common surgical morbidity. Surgical morbidity was significantly higher in patients who underwent rectal surgery $(p=0.0124)$. Ten (15.9\%) patients experienced medical morbidities. The most common medical morbidity was atrial fibrillation (7.9\%) (Table 3). The median LOS was 14 (3-39) days. Development of surgical morbidity $(p=0.0004)$ and medical morbidity $(p=0.0288)$ was the factor that negatively affects the LOS.

There was only 1 (1.58\%) perioperative mortality. This patient underwent LAR for rectal cancer after completion of neoadjuvant chemo radiotherapy, and he was reoperated for anastomotic leak on postoperative day 6 . The patient died as a result of intra-abdominal sepsis on postoperative day 21 .

\section{DISCUSSION}

The number of elderly people within the population has been progressively growing parallel to the increasing life expectancy. According to the World Health Organization, describing ages over 80 years old as "very old," the very old group appears to be the most prevalently growing group among the population (6). The very old people represent $1.03 \%$ of the total population in 2007 , and its number increased 1.5 -fold to $1.52 \%$ in 2013 (7).

In the present study, $8.2 \%$ of the patients who underwent operations due to colorectal cancer were octogenarians. This ratio was $9.6 \%$ in the study performed by Nyam et al. in Singapore (8) and $15.4 \%$ in the multicenter study performed by Marusch et al. (9) in Germany. As society becomes older, surgeons more frequently encounter octogenarians. The number of octogenarians undergoing operations for colorectal cancer in countries with a long life expectancy and a large elderly population, such as Germany, is nearly two-fold that of countries such as Turkey and Singapore. 


\begin{tabular}{|c|c|c|c|}
\hline $\begin{array}{l}\text { Surgical } \\
\text { Procedure (n, \%) }\end{array}$ & $\begin{array}{l}\text { Emergency } \\
\qquad(n=11)\end{array}$ & $\begin{array}{l}\text { Elective } \\
(n=52)\end{array}$ & $\begin{array}{l}\text { Total } \\
(n=63)\end{array}$ \\
\hline Right hemicolectomy & $1(1.6)$ & $9(14.3)$ & $10(15.9)$ \\
\hline Left hemicolectomy & $1(1.6)$ & $5(7.9)$ & $6(9.5)$ \\
\hline Anterior resection & - & $12(18)$ & $12(18)$ \\
\hline Low anterior resection & - & $14(22.2)$ & $14(22.2)$ \\
\hline $\begin{array}{l}\text { Abdominoperineal } \\
\text { resection }\end{array}$ & - & $4(6.3)$ & $4(6.3)$ \\
\hline Hartmann & $6(9.5)$ & $3(4.8)$ & $9(13.3)$ \\
\hline $\begin{array}{l}\text { Total*/subtotal } \\
\text { colectomy }\end{array}$ & $3(4.8)$ & $2(3.2)$ & $5(8)$ \\
\hline Turnbull-Cutait & - & $1(1.6)$ & $1(1.6)$ \\
\hline Bypass & - & $1(1.6)$ & $1(1.6)$ \\
\hline Transanal local excision & - & $1(1.6)$ & $1(1.6)$ \\
\hline \multicolumn{4}{|c|}{$\begin{array}{l}\text { *Total colectomy was necessary in one patient with synchronous colorectal } \\
\text { tumor }\end{array}$} \\
\hline
\end{tabular}

\begin{tabular}{|lcc|}
\hline Table 2. Characteristics of cancer & & \\
\hline $\begin{array}{l}\text { Pathological diagnosis of colorectal } \\
\text { cancer }\end{array}$ & Rate (\%) \\
\hline Adenocarcinoma & 57 & 90.5 \\
\hline Mucinous adenocarcinoma & 3 & 4.8 \\
\hline Signet ring cell carcinoma & 1 & 1.59 \\
\hline Malign melanoma & 1 & 1.59 \\
\hline Lymphoma & 1 & 1.59 \\
\hline $\begin{array}{l}\text { Distribution of the disease stage } \\
\text { (adenocarcinoma) }\end{array}$ & \\
\hline Stage I & 6 & 10 \\
\hline Stage IIA & 14 & 23.4 \\
\hline Stage IIIB & 22 & 36.6 \\
\hline Stage IIIC & 8 & 13.3 \\
\hline Stage IVA & 10 & 16.6 \\
\hline AJCC: American Joint Committee on Cancer (7th & & \\
\hline
\end{tabular}

The rate of ASA III patients was $26.9 \%$ in our study, whereas it was $59.8 \%$ in the study by Ming-gao et al. (2) and $81 \%$ in the study performed by Tsar'kov et al. (10). Neither the ASA score nor the corresponding presence of concomitant diseases affected morbidity or mortality. However, the low rate of ASA III patients, the predominance of ASA II patients, and the lack of ASA IV, V, and VI patients limited the evaluation of the effect of the ASA score on postoperative outcomes in our study. Nonetheless, previous studies from our department found that there is a correlation between mortality and ASA score $(11,12)$.

Ong et al. (13) reported rates of 55\% for right colon cancer, $19 \%$ for left colon cancer, and $26 \%$ for rectal cancer. Additionally, these rates were $20 \%$ for right colon cancer, $46 \%$ for left colon cancer, and $34 \%$ for rectal cancer in the study, and they varied in different cultures $(3,9,14-16)$. Many studies from Western countries have shown that the number of right-sided cancers progressively increases as age increases (17). Zhang et al. (18) reported that the rate of right colon cancer in pa-

\begin{tabular}{|c|c|c|c|}
\hline Morbidity & $\mathbf{n}$ & Rate (\%) & Treatment \\
\hline $\begin{array}{l}\text { Surgical } \\
\text { morbidities }\end{array}$ & 12 & 19 & \\
\hline $\begin{array}{l}\text { latrogenic splenic } \\
\text { injury }\end{array}$ & 1 & 1.6 & Splenectomy \\
\hline $\begin{array}{l}\text { Intra-abdominal } \\
\text { abscess }\end{array}$ & 1 & 1.6 & $\begin{array}{c}\text { Percutaneous } \\
\text { drainage }\end{array}$ \\
\hline Eventration & 2 & 3.2 & Reoperation \\
\hline Anastomotic leak & 3 & 4.7 & $\begin{array}{l}\text { Reoperation } \\
\text { (all were rectal } \\
\text { resections) }\end{array}$ \\
\hline $\begin{array}{l}\text { Surgical site } \\
\text { infection }\end{array}$ & 5 & 7.9 & $\begin{array}{c}\text { Debridement } \\
\text { and } \\
\text { antibiotherapy }\end{array}$ \\
\hline \multicolumn{4}{|l|}{$\begin{array}{l}\text { Medical } \\
\text { morbidities* }\end{array}$} \\
\hline $\begin{array}{l}\text { Urinary tract } \\
\text { infection }\end{array}$ & 1 & 1.6 & \\
\hline Pneumonia & 3 & 4.7 & \\
\hline Atrial fibrillation & 5 & 7.9 & \\
\hline $\begin{array}{l}\text { Pneumonia+atrial } \\
\text { fibrillation }\end{array}$ & 1 & 1.6 & \\
\hline
\end{tabular}

*No medical morbidities required surgical intervention

tients aged over 75 years is $34.6 \%$, whereas it is $20 \%$ in patients younger than 75 years. The right-sided tumor rate was $17.5 \%$ in the present study. Although our department is a referral center in the region, those patients might be referred less frequently due to the lower complexity of right colectomy compared with left colectomy and rectal resections.

Preoperative blood transfusion was detected as a risk factor for increasing postoperative morbidity. Halabi et al. (19) reported that blood transfusion increases the mortality, morbidity, and LOS in 27,120 patients who underwent operations for colorectal cancer in California. We believe that the need for blood transfusion is also a factor that reflects the complexity of the case.

Stoma creation was necessary in 19 (30.1\%) patients, and 42\% of them were admitted as emergency cases. The reported stoma creation rates were higher in a previous study (2). While $50.8 \%$ of the tumors were localized at the left colon and $31.7 \%$ at the rectum, the rate of patients who underwent a Hartmann's procedure was $13.3 \%$. The complication rates of the Hartmann's procedure have been reported to vary between $20 \%$ and $69 \%$ in different series (20). Most importantly, the difficulty of the Hartmann's procedure necessitates another intervention to sustain intestine continuity. Higher stoma reversal failure rate is the major disadvantage of the Hartmann's procedure. Sücüllü et al. (21) stated that the Hartmann's procedure must be performed very selectively, especially for elderly patients with cancer, and that in general, it must be considered as a possible permanent procedure.

In our study, most of the patients were Duke C patients, whereas one-third of the study population represented Duke $A$ and $B$ patients. Half of the patients in developed countries, such as France, United Kingdom, Germany, and Japan, are Duke A and 
B patients, with a predominance of Duke B patients. In these countries, half of the patients do not need adjuvant treatment after surgery. Therefore, the burdens on patients, doctors, and the economy decrease as both the toxic effects of adjuvant treatment on patients and the utilization of treatments that are used to reduce these effects decrease.

In the present study, 19\% of the patients experienced surgical morbidity, and it was significantly frequent in patients who underwent surgery for rectal cancer. It must be noted that limited number of ASA III-IV patients, limited number of emergency procedures, and patients with advanced stage tumors may yield false negative results. Although a multicenter study from Germany (9) observed a surgical morbidity rate of $20 \%$, the ASA score, emergency surgery, and presence of concomitant diseases (cardiac, respiratory, and renal) affected morbidity. In another study, the rate of surgical morbidity was $8.8 \%$, and the only factor affecting morbidity was emergency admission (13). Almost $16 \%$ of the patients experienced medical morbidity. Although it was not a significant variable in the development of medical morbidity, studies have associated surgery itself with medical morbidity (17). Additionally, the ASA score and emergency admission were reported to be other risk factors (9).

Length of total hospital stay was another variable in our study. The mean LOS was 14 days in our series. The factors that affect the LOS were medical and surgical morbidities. Unfortunately, the number of studies evaluating the effects of age on the LOS is limited (22). Advanced age may be a factor lengthening the LOS since surgeons are more comfortable when they monitor the elderly patients longer before hospital discharge. Methodological studies focusing on this issue are needed to identify why elderly patients have a longer duration of hospitalization and to determine the factors that affect this duration.

In the present study, the rate of perioperative mortality was $1.58 \%$. The rate ranges from $5.2 \%$ to $10 \%$ according to previous studies $(8,17,23)$. Similar to previous data, the morbidity and mortality rates were reduced in our center since patients were operated by surgeons who were specialized in colorectal surgery (24). Evaluation of the patient-related factors that affect mortality is not appropriate owing to the presence of only one mortality; however, Grosso et al. (25) and Öztürk and Yılmazlar (11) from our clinic stated that the ASA score and concomitant diseases are factors that affect mortality.

The major limitation of the present study was its retrospective design. A low number of ASA III and IV patients may be another limitation that can affect the results. On the other hand, this is one of the largest series studied outcomes of colorectal cancer surgery in octogenarians from our country.

\section{CONCLUSION}

The number of octogenarian patients in society increases as life expectancy increases. The most important risk factor for colorectal cancer is age, and its incidence will continue to increase as societies become older. Surgeons tend to avoid operating on octogenarians since advanced age is considered as a risk factor. However, as demonstrated safely with acceptable morbidity and mortality rates in specialized centers.

Ethics Committee Approval: Ethics committee approval was received for this study from the Ethics Committee of Uludag University School of Medicine.

Informed Consent: Informed consent was not received due to the retrospective nature of the study.

Peer-review: Externally peer-reviewed.

Author Contributions: Concept - B.G., T.Y.; Design - B.G., T.Y.; Supervision - E.Ö., T.Y.; Resource - B.G., Ö.I.; Materials - B.G., Ö.I., E.Ö.; Data Collection and/or Processing - B.G., Ö.l.; Analysis and/or Interpretation - B.G., Ö.I., E.Ö.; Literature Search - B.G., Ö.I.; Writing Manuscript - B.G., Ö.I., T.Y.; Critical Reviews - E.Ö., T.Y.

Conflict of Interest: The authors have no conflicts of interest to declare.

Financial Disclosure: The authors declared that this study has received no financial support.

\section{REFERENCES}

1. Vignali A, Di Palo S, Tamburini A, Radaelli G, Orsenigo E, Staudacher C. Laparoscopic vs. open colectomies in octogenarians: a case-matched control study. Dis Colon Rectum 2005; 48: 20702075. [CrossRef]

2. Ming-Gao G, Jian-Zhong D, Yu W, You-Ben F, Xin-Yu H. Colorectal cancer treatment in octogenarians: elective or emergency surgery?, World J Surg Oncol 2014; 12: 386. [CrossRef]

3. Tan KY, Chen CM, Ng C, Tan SM, Tay KH. Which octogenarians do poorly after major open abdominal surgery in our Asian population? World J Surg 2006: 547-552. [CrossRef]

4. Baek SJ, Kim SH, Kim SY, Shin JW, Kwak JM, Kim J. The safety of a "fast-track" program after laparoscopic colorectal surgery is comparable in older patients as in younger patients. Surg Endosc 2013; 27: 1225-1232. [CrossRef]

5. Pawa N, Cathcart PL, Arulampalam TH, Tutton MG, Motson RW. Enhanced recovery program following colorectal resection in the elderly patient. World J Surg 2012; 36: 415-423. [CrossRef]

6. Aging and life course. Available from URL: http://www.who.int/ ageing/about/facts/en/. Access Date: 02 October 2014.

7. İstatistikle Yaşlılar. Available from URL: http://www.tuik.gov.tr/ PreHaberBultenleri.do?id=16057. Access Date: 04 October 2014.

8. Nyam DCNK, Tang CB, Ang M, Ho YH, Leong AFPK, Seow-Choen F. Surgery for colorectal cancer in the octogenerians. Tech Coloproctol 1999: 23-26. [CrossRef]

9. Marusch F, Koch A, Schmidt U, Steinert R, Ueberrueck T, Bittner $\mathrm{R}$, et al. The impact of the risk factor "age" on the early postoperative results of surgery for colorectal carcinoma and its significance for peroperative management. World J Surg 2005; 29: 1013-1021. [CrossRef]

10. Tsar'kov PV, Nikoda VV, Stamov VI, Markar'ian DR, Tulina IA. The efficacy of the multidisciplinary approach in colorectal cancer surgery in elderly patients. Khirurgiia (Mosk) 2012: 4-13.

11. Ozturk E. Yilmazlar T. Factors affecting the mortality risk in elderly patients undergoing surgery. ANZ J Surg 2007; 77: 156159. [CrossRef]

12. Yilmazlar T, Guner O, Yilmazlar A. Criteria to consider when assessing the mortality risk in geriatric surgery. Int Surg 2006; 91 : 72-76.

13. Ong ES, Alassas M, Dunn KB, Rajput A. Colorectal cancer surgery in the elderly: acceptable morbidity?. Am J Surg 2008; 195: 344348. [CrossRef] 
14. Leong QM, Aung MO, Ho CK, Sim R. Emergency colorectal resections in Asian octogenarians: factors impacting surgical outcome. Surg Today 2009; 39: 575-579. [CrossRef]

15. Barrier A, Ferro L, Houry S, Lacaine F, Huguier M. Rectal cancer surgery in patients more than 80 years of age. Am J Surg 2003; 185: 54-57. [CrossRef]

16. Smith JJ, Lee J, Burke C, Contractor KB, Dawson PM. Major colorectal cancer resection should not be denied to the elderly. Eur J Surg Oncol 2002; 28: 661-666. [CrossRef]

17. Gurevitch AJ, Davidovitch B, Kashtan H. Outcome of Right Colectomy for Cancer in Octogenerians. J Gastrointest Surg 2009: 100104. [CrossRef]

18. Zhang B, Fattah A, Nakama H. Characteristics and survival rate of elderly patients with colorectal cancer detected by immunochemical occult blood screening. Hepatogastroenterology 2000; 47: 414-418.

19. Halabi WJ, Jafari MD, Nguyen VQ, Carmichael JC, Mills S, Pigazzi $A$, et al. Blood transfusions in colorectal cancer surgery: incidence, outcomes, and predictive factors: an American College of
Surgeons National Surgical Quality Improvement Program analysis. Am J Sur 2013; 206: 1024-1032. [CrossRef]

20. Desai DC, Brennan EJ Jr, Reilly JF, Smink RD Jr. The Utility of the Hartmann Procedure. Am J Surg 1998; 175: 152-154. [CrossRef]

21. Sücüllü I, Demirbaş S, Yücel E, Filiz I, Kurt Y, Akın L. Hartmann's Procedure: Should it be Performed? Kolon Rektum Hast Derg 2007; 17: 26-30.

22. Fazio VW, Tekkis PP, Remzi F, Lavery IC. Assessment of operative risk in colorectal cancer surgery: the Cleveland Clinic Foundation colorectal cancer model. Dis Colon Rectum 2004; 47: 2015-2024. [CrossRef]

23. Kunitake $\mathrm{H}$, Zingmond DS, Ryoo J, Ko CY. Caring for octogenarian and nonagenarian patients with colorectal cancer: what should our standards and expectations be?. Dis Colon Rectum 2010; 53: 735-743. [CrossRef]

24. Çolak T, Türkmenoğlu Ö, Dağ A, Gündoğdu R, Aydın S. Does establishment of colorectal surgical unit improve colorectal operations? Ulus Cerrahi Derg 2009; 25: 49-52.

25. Grosso G, Biondi A, Marventano S, Mistretta A, Calabrese G, Basile F. Major postoperative complications and survival for colon cancer elderly patients. BMC Surgery 2012; 12: 20. [CrossRef] 